compulsory by the issue of statutory rules and orders. The preparation of standards for building materials and appliances now being carried out in support of the programme of house-building of the Ministries of Works and Health has already reached substantial proportions. Sir Percy concluded by emphasizing the importance of industrial standards, which provide for accurate and precise trade descriptions, methods of sampling and testing, and standards of performance, and of an independent body, set up and maintained by the national industry as a whole, with Government support but not under Government control; for the preparation of such standards. Progress will be most widespread and continuous if the policy of 'standardization by consent' is consistently pursued.

\section{Harvesting Machinery}

THE inaugural meeting of the 1944-45 session of the Institution of British Agricultural Engineers was held on October 17 at the Institution of Electrical Engineers under the chairmanship of Mr. C. I. C. Bosanquet, and Mr. Cornelius Davies read a paper on harvesting machinery. Mr. Davies, who has for many years been closely associated with the South-Eastern Agricultural College at Wye, Kent, traced the developments in methods of harvesting from the earliest times to the present day. His paper dealt not only with the harvesting of corn and potatoes but also with machinery for handling sugar beet, grass, silage, hops, vegetables and fruit. On the combine harvester Mr. Davies reminded the audience that this machine cuts and threshes the grain in one operation, and there is no period in the stook when final ripening can take place. Adequate drying facilities are necessary, and serious attention to grain storage is required. Nearly all combine owners are faced with a straw problem. $\mathrm{He}$ considers that to burn straw is evidence of bad husbandry. On some farms pick-up balers are used, but the cost of these is nearly as high as that of a combine; further, the use to which the baled straw can be put must be considered.

On the question of potato harvesting Mr. Davies discussed the relative merits of the spinner and the elevator lifter, and stressed the need that still exists for a really satisfactory potato harvester. In conclusion, Mr. Davies stated that in addition to the provision of more and better harvesting machines, there must be more skill in handling and greater care in maintaining and managing agricultural machinery. In the discussion which ensued, community ownership of expensive machines, the employment of contractors, and the development of simple and relatively inexpensive machines within the scope of private ownership on small farms were discussed.

\section{Cultural Co-operation}

UNDER the title "The Cultural Co-operation Program 1938-1943" (Washington: Govt. Printing Office. 15 cents), the U.S. Department of State has issued a report by $H$. Hanson describing the development since its inception of this programme for fostering international relations on a basis of mutual understanding and appreciation. The programme is conceived by the General Advisory Committee of the Division of Cultural Relations as a long-term one of continuing activities which should be as broad as intellectual and cultural activities themselves. A statement of policy issued by the Department on March 31, 1944, on the participation of the United
States in educational and cultural reconstruction in Europe, indicated the Department's intention of co-operating in the formation of a United Nations organization for educational and cultural reconstruction. This emergency programme to meet this need may consist of assistance in restocking essential educational facilities, especially books and scientific and other teaching aids; in the provision of opportunities for training carefully selected foreign students in American educational institutions; in re-establishing essential library facilities; and in the recovery and restoration to their rightful owners of scientific, artistic and archival materials looted by the Axis countries. The report includes some notes on professional and scientific relations, and on the various activities under the programme: these include travel and study grants, including student exchange, and the provision of technical experts for China; cultural centres, such as libraries, including the reference library opened by the Office of War Information in London in December 1942, which seeks by a careful loan service to place each new American book in the hands of selected people in the British Isles; cultural materials, such as books for libraries in the Western hemisphere, book translations, microflims for China and the Near East, science news letters and motion pictures and radio activities.

\section{Pitfalls of Positivism}

IN a most timely article entitled "Positivism" (Mind, July 1944), Prof. W. T. Stace throws great light on the doctrinaire character of the so-called logical positivists. After making a useful distinction between the 'meaning' of a word and the 'significance' of a sentence, he states the positivist principle as follows: "what makes a sentence significant is that some actual or possible observation can be deduced from it in conjunction with certain other premises, without being deducible from those other premises alone". He then makes his main point, that underlying this principle is another one more fundamental, which he calls the "Principle of Observable Kinds", and states as follows, "a sentence, to be significant, must assert or deny facts of a kind such that it is logically possible directly to observe some facts which are instances of that kind".

Prof. Stace points out that this principle is different from the positivist principle in that it introduces the notion of direct verification, whereas the positivist principle makes use of that of indirect verification. Further, this latter principle neither follows from the positivist principle nor is it self-evident. Nor again does it follow from the empiricist principle which states that all our simple ideas come from impressions, because this provides no guide as to how the former are to be combined to make significant sentences. In fact, Prof. Stace holds that there is no reason to think the principle true. It would follow that we should discard it and with it the positivist principle, if in fact this latter is based on it. But the proof which Prof. Stace gives that the two are related in this way is weak. Nevertheless, all those inclined to flirt with modern forms of positivism should study the article.

\section{Physical Society's Exhibition of Scientific Instru- ments and Apparatus}

THE Physical Society's long and almost continuous series of annual exhibitions of scientific instruments and apparatus was, of necessity, suspended during the War. Its resumption has recently been considered by the Council of the Society and by the Exhibition 